\title{
Karakteristik Karkas dan Non Karkas Ayam Broiler Jantan dan Betina pada Umur Pemotongan 30 Hari
}

\author{
Characteristics of carcass and non carcass of male and female broiler chickens at 30 days of cutting age \\ N. Ulupi ${ }^{1}$, H. Nuraini ${ }^{1}$, J. Parulian ${ }^{1}$, \& S. Q. Kusuma ${ }^{1}$ \\ ${ }^{1}$ Departemen Ilmu Produksi dan Teknologi Peternakan, Fakultas Peternakan, IPB \\ Jl. Agatis Kampus IPB Dramaga, Bogor 16680 Indonesia \\ Email koresponden author: niken.ulupi@gmail.com
}

\begin{abstract}
The population of commercial broiler chickens in Indonesia is increasing along with the high level of consumption of Indonesian poultry meat. The difference in the weight of broiler chicken harvest due to sex differences allows for differences in the percentage of carcass, non carcass and physical quality of broiler chicken meat. The aim of study was to analysis the sex differences in broiler chickens against the carcass and non carcass characteristics produced. 10 broiler chickens, each of male and female aged 30 days randomized from 14000 broiler chickens that maintained in closed house were analyzed. The variables observed were carcass characteristics (carcass percentage, cut up of carcass, edible and non edible carcass components, and physical quality of breast meat) and non carcass characteristics (non carcass components). The data obtained were analyzed using the t-test. The average body weight of male and female chickens were $1834.10 \mathrm{~g}$ and $1659.40 \mathrm{~g}$. The carcases percentage of male and female broilers were $69.38 \%$ and $70.78 \%$. The bone percentage of male and female broilers were $17.27 \%$ and $15.56 \%$. The cooking shrinkage value of male and female broilers breast meat were $36.32 \%$ and $42.50 \%$. As a conclusion, male broilers with greater body weight produced a smaller significant of carcas percentage, and a significantly greater of bone percentage, but had better in physical quality than female broiler chickens.
\end{abstract}

Keywords: broiler chicken, carcass, non carcass, phsyical quality of meat

\section{PENDAHULUAN}

Ayam pedaging memberikan sumbangan besar terhadap pemenuhan kebutuhan protein hewani masyarakat Indonesia, karena proses produksi ayam pedaging yang relatif cepat, mudah diperoleh di pasar dan harganya relatif murah dibanding sumber protein hewani lainnya. Data BPS (2017) menunjukan setiap tahunnya populasi ayam ras pedaging atau broiler mengalami kenaikan. Pada tahun 2013 produksi daging ayam broiler sebesar 1.344.191.104 ekor, mengalami pertumbuhan hingga tahun 2017 sebesar 1.698.368.741 ekor. Hasil rata-rata 5 tahun terakhir, populasi ayam broiler setiap tahunnya meningkat sebesar 90.793.344,8 ekor tahun ${ }^{-1}$.

Ayam broiler adalah ayam jantan atau betina yang umumnya dipanen pada umur 4-5 minggu dengan tujuan sebagai penghasil daging (Kartasudjana dan Suprijatna 2006). Pemeliharaan ayam broiler di Indonesia pada umumnya secara intensif dengan pakan komersial, tanpa membedakan jenis kelamin. Padahal dari nilai ekonomis dan kebutuhan gizi, formulasi ransum pakan ayam jantan dan betina berbeda. Selain itu ayam broiler dipanen berdasarkan indikator bobot potong saja. Padahal ayam jantan pada waktu panen yang sama dapat mencapai bobot potong yang lebih tinggi dibandingkan ayam betina (NRC 1994).

Ayam broiler biasa dipasarkan dalam bentuk karkas. Karkas adalah bagian tubuh ayam setelah dilakukan penyembelihan secara halal, pengeluaran darah, pencabutan bulu dan pengeluaran jeroan, tanpa kepala, leher, dan kaki (SNI 2009). Karkas ayam broiler biasa dipasarkan secara utuh maupun potongan. Umumnya potongan komersial karkas ayam broiler meliputi bagian sayap, dada, paha, dan punggung. Sejauh ini belum diketahui apakah pada umur panen yang sama, ayam broiler jantan dan betina menghasilkan karkas dengan karakteristik yang sama. Oleh karena itu tujuan dari penelitian ini adalah mengkaji karakteristik karkas, non karkas, dan sifat fisik daging ayam broiler yang berasal dari jenis kelamin berbeda.

\section{MATERI DAN METODE}

\section{Bahan dan Alat}

Penelitian ini bertempat Laboratorium Lapang Unggas Blok B, Laboratorium Ilmu Produksi Ternak Ruminansia Besar, Fakultas Peternakan, Institut Pertanian 
Bogor. Ternak yang digunakan pada penelitian ini adalah ayam broiler strain Cobb jantan dan betina berumur 30 hari yang dipelihara dalam kandang closed house. Setiap jenis kelamin diambil sample secara acak sebanyak masingmasing 10 ekor. Pengujian sifat fisik daging dari setiap ayam diambil dari bagian dada.

Alat yang digunakan saat pemotongan adalah polyethilen, talenan, pisau untuk pemotongan dan deboning, scalpel, timbangan digita, kompor, panci, piring, chiller, termometer bimetal, corer, pH meter HANNA HI 99163, kertas saring Whatman-41, carperpress, Warner Bratzle Shear Force, borang penelitian, dan alat tulis.

\section{Pemotongan}

Pemotongan ayam dilakukan berdasarkan pedoman dari Direktorat Jendral Peternakan dan Kesejahteraan Hewan (2010). Ayam dipuasakan dari pakan selama 12 jam. Sebelum dipotong ayam ditimbang untuk mengetahui bobot potong. Ayam dipotong sesuai metode sembelih halal dengan memotong saluran pernafasan (trakea), kerongkongan (esofagus), dan pembuluh darah (vena jugolaris dan arteri karotidea).

Ayam dibiarkan selama 2-3 menit atau sampai ayam sudah tidak bergerak dan tidak ada darah yang keluar. Selanjutnya ayam ditimbang dan dilakukan scalding (pada 52-55 ${ }^{\circ} \mathrm{C}$, 90-120 detik), pencabutan bulu, pengeluaran jerohan, pemotongan kepala, leher dan kaki. Pada setiap tahapan tersebut dilakukan penimbangan. Karkas yang diperoleh didinginkan kemudian ditimbang.

Karkas dipotong menjadi beberapa bagian potongan yaitu sayap, dada, paha atas, paha bawah, dan punggung untuk ditimbang (Soeparno 2005). Setiap bagian tersebut ditimbang dan selanjutnya dilakukan pemisahan antara kulit, daging dan tulang. Kulit, daging dan tulang dari masing-masing bagian potongan karkas tersebut kemudian ditimbang.

\section{Sifat Fisik Daging}

Analisis sifat fisik daging dilakukan pada daging dada seluruh ayam broiler (Jantan dan betina). Pengujian dilakukan terhadap peubah $\mathrm{pH}$ (potensial of hidrogen), persentase $\mathrm{mg} \mathrm{H}_{2} \mathrm{O}$, susut masak, dan keempukan.

Pengukuran $\mathrm{pH}$ daging dibantu menggunakan alat pH meter HANNA H1 99163 yang telah dikalibrasi. Lalu pH meter ditusukkan ke dalam daging bagian dada lalu ditunggu hingga nilai $\mathrm{pH}$ pada $\mathrm{pH}$ meter tetap. Pengukuran $\mathrm{pH}$ daging dilakukan sebanyak 2 kali dan diambil rataratanya.

Daya mengikat air ditentukan dengan metode Hamm (1972 dalam Soeparno 2005) yaitu dengan membebani atau mengepres $0,3 \mathrm{~g}$ sampel daging dengan beban $35 \mathrm{~kg}$ pada suatu kertas saring diantara 2 plat kaca selama 5 menit. Area yang tertutup sampel daging yang telah menjadi pipih, dan luas area basah sekelilingnya pada kertas saring beserta sampel daging ditandai dan setelah pengepresan selesai, dapat diukur (misalnya digambar pada kertas grafik). Area basah diperoleh dengan mengurangkan area yang tertutup daging dari area total yang meliputi pula area basah pada kertas saring. Persentase air bebas dihitung menggunakan rumus sebagai berikut:

$$
\begin{aligned}
\mathrm{H}_{2} \mathrm{O}(\mathrm{mg}) & =\frac{\operatorname{area~basah}\left(\mathrm{cm}^{2}\right)}{0.0948}-8.0 \\
\mathrm{H}_{2} \mathrm{O}(\%) & =\frac{\mathrm{H}_{2} \mathrm{O}(\mathrm{mg})}{300 \mathrm{mg}} \times 100 \%
\end{aligned}
$$

Susut masak adalah perbedaan antara berat daging sebelum dan sesudah dimasak, dinyatakan dalam persentase (\%). Susut masak diukur pada bagian daging dada. Daging ditusuk dengan termometer bimetal. Daging direbus hingga mencapai suhu internal $81^{\circ} \mathrm{C}$. Sampel daging diangkat dan didiamkan sampai mencapai berat konstan. Susut masak dihitung dengan rumus sebagai berikut:

$$
\text { Susut masak }(\%)=\frac{\text { Berat awal }- \text { Berat akhir }}{\text { Berat awal }} \times 100 \%
$$

Keempukan dilakukan dengan metode irisan (Aberle et al. 2001). Daging dada direbus hingga suhu internal mencapai $81{ }^{\circ} \mathrm{C}$. Lalu daging dicetak menggunakan corer dengan diameter $1,27 \mathrm{~cm}$. Tingkat keempukan daging ditunjukkan oleh besarnya kekuatan $\left(\mathrm{kg} \mathrm{cm}^{-2}\right)$ yang diperlukan untuk memotong core daging yang ditunjukkan oleh jarum penunjuk alat pemotong daging Warner Bratzler Device yang bergerak di atas skala dengan kepekaan pengukuran $0,1 \mathrm{~kg} \mathrm{~cm}^{-2}$.

\section{Analisis Data}

Faktor yang ingin diketahui perbedaannya dalam penelitian ini adalah jenis kelamin ayam broiler yang berbeda (jantan dan betina) pada umur panen 30 hari, dengan ulangan sebanyak 10 ekor dan setiap unit percobaan terdiri atas 1 ekor ayam broiler. Peubah yang diamati adalah karakteristik karkas (bobot hidup, bobot, dan persentase karkas, serta bobot dan persentase bagian-bagian karkas, karkas edible dan karkas non edible, serta kualitas fisik daging dada), karakteristik non karkas (bobot dan persentase non karkas). Data yang diperoleh dianalisis menggunakan uji-t sebagai berikut (Steel dan Torrie 1993):

$$
t_{\text {hit }}=\frac{\left(\overline{\mathrm{x}}_{1}-\overline{\mathrm{x}}_{2}\right)}{\sqrt{\frac{\left(n_{1}-1\right) S_{1}^{2}+\left(n_{2}-1\right) S_{2}^{2}}{n_{1}+n_{2}-2}\left(\frac{1}{n_{1}}+\frac{1}{n_{2}}\right)}}
$$

Keterangan:

$\mathrm{t}$ : nilai t hitung;

$\overline{\mathrm{x}}_{1}$ : rata-rata ayam broiler jantan umur 30 hari;

$\overline{\mathrm{x}}_{2}$ : rata-rata ayam broiler betina umur 30 hari;

$\mathrm{S}_{1}$ : simpangan baku ayam broiler jantan umur 30 hari;

$\mathrm{S}_{2}$ : simpangan baku ayam broiler betina umur 30 hari;

$\mathrm{n}_{1}$ : jumlah sampel ayam broiler jantan umur 30 hari; dan

$\mathrm{n}_{2}$ : jumlah sampel ayam broiler betina umur 30 hari $(\mathrm{kg})$.

\section{HASIL DAN PEMBAHASAN}

\section{Bobot Potong, Bobot Karkas, dan Non Karkas}

Bobot potong merupakan bobot hasil penimbangan sebelum proses pemotongan ayam broiler. Hasil analisis 
bobot potong, bobot karkas, dan non karkas ayam broiler jantan dan betina pada umur 30 hari disajikan pada Tabel 1 .

Berdasarkan Tabel 1, pada umur panen yang sama (30 hari), bobot potong ayam jantan lebih besar dibandingkan ayam betina. Hal ini disebabkan karena adanya dimorfisme seksual. Ayam jantan memiliki hormon testosterone. Pada periode pertumbuhan, hormone tersebut bersinergi dengan growth hormon mempengaruhi pertumbuhan ayam, sehingga ayam jantan tumbuh lebih cepat. Murawska et al. (2011) menyatakan bahwa laju pertumbuhan ayam jantan lebih besar dibandingkan ayam betina sejak berumur 4 minggu.

Bobot potong pada penelitian ini lebih besar dibandingkan penelitian Setiawan dan Sujana (2015) yaitu sebesar 1636 g ekor $^{-1}$ (ayam betina) dan 1773 g ekor $^{-1}$ (ayam jantan). Perbedaan tersebut terjadi karena adanya perbedaan sistem perkandangan. Pada penelitian ini, ayam dipelihara dalam kandang sistem closed house, dengan suhu yang diatur pada comfort zone $\left(21-24^{\circ} \mathrm{C}\right)$. Pada lingkungan suhu tersebut, sistem metabolisme pada ayam berfungsi dengan baik (Bell dan Weaver, 2002) sehingga ayam tumbuh lebih baik dan menghasilkan bobot badan yang lebih tinggi (Qurniawan et al. 2016).

Karkas merupakan bagian tubuh ayam yang memiliki nilai ekonomis tinggi. Berbeda dengan bobot badannya, dalam penelitian ini ayam broiler jantan nyata menghasilkan persentase karkas yang lebih rendah dari ayam betina. Persentase non karkas ayam broiler jantan lebih besar dibandingkan ayam betina dan berbanding terbalik dengan persentase karkasnya. Hasil persentase karkas pada penelitian ini sebesar 72,25\%-73,77\%, hasil tersebut hampir sama dengan hasil penelitian Setiawan dan Sujana (2015) yaitu sebesar 73,75\%.

\section{Karakteristik Karkas Ayam Broiler}

Pembahasan karakteristik karkas ayam broiler diawali dengan menyajikan persentase potongan komersial karkas (Tabel 2), yang terdiri atas bagian dada, paha, sayap dan punggung. Selanjutnya diuraikan mengenai besarnya komponen karkas edible dan non edible (Tabel 3) dan diakhiri dengan pembahasan mengenai pengaruh jenis Hasil analisis menunjukkan bahwa persentase potongan karkas komersial dari ayam broiler jantan dan ayam betina tidak berbeda nyata. Persentase bagian dada pada penelitian ini sebesar 42,84\%-43,02\%. Hasil tersebut lebih besar dibandingkan penelitian Nittha et al. (2017) sebesar 31,71\%
Tabel 2. Persentase potongan komersial karkas ayam broiler jantan dan betina pada umur potong 30 hari

\begin{tabular}{rrr}
\hline Peubah & \multicolumn{1}{c}{ Jantan } & \multicolumn{1}{c}{ Betina } \\
\hline Dada $(\mathrm{g})$ & $534,65 \pm 32,51$ & $505,29 \pm 21,29$ \\
$(\%)$ & $42,02 \pm 1,66$ & $43,02 \pm 1,44$ \\
Paha $(\mathrm{g})$ & $375,27 \pm 12,67$ & $331,39 \pm 16,90$ \\
$(\%)$ & $29,49 \pm 0,46$ & $28,22 \pm 1,40$ \\
Sayap (g) & $126,38 \pm 9,82$ & $119,49 \pm 10,71$ \\
$(\%)$ & $9,93 \pm 2,31$ & $10,17 \pm 2,67$ \\
Punggung (g) & $236,08 \pm 14,89$ & $218,27 \pm 16,47$ \\
$(\%)$ & $18,56 \pm 4,89$ & $18,59 \pm 16,47$ \\
\hline
\end{tabular}

Angka disertai huruf kecil yang berbeda pada baris yang sama menunjukkan berbeda nyata $(\mathrm{P}<0,05)$

Tabel 3. Rataan bobot dan persentase edible dan non edible dari karkas ayam broiler

\begin{tabular}{rcc}
\hline \multicolumn{1}{l}{ Peubah } & Jantan & Betina \\
\hline Karkas edible & & \\
Daging (g) & $865,65 \pm 50,67$ & $804,48 \pm 35,30$ \\
$(\%)$ & $68,03 \pm 2,14$ & $68,50 \pm 1,31$ \\
Kulit (g) & $186,99 \pm 13,28$ & $187,17 \pm 27,06$ \\
$(\%)$ & $14,70 \pm 0,57$ & $15,94 \pm 1,57$ \\
Karkas non edible & & \\
Tulang (g) & $219,74 \pm 15,77$ & $182,79 \pm 15,76$ \\
$(\%)$ & $17,27 \pm 0,89 \mathrm{a}$ & $15,56 \pm 0,68 \mathrm{~b}$ \\
\hline
\end{tabular}

Angka disertai huruf kecil yang berbeda pada baris yang sama menunjukkan berbeda nyata $(\mathrm{P}<0,05)$

dan penelitian Muiz (2016) sebesar 34\%. Persentase bagian paha yang diperoleh dalam penelitian ini lebih kecil dan persentase bagian sayap serta punggung hampir sama dengan ke dua peneliti tersebut diatas.

Setelah dilakukan pemisahan antara kulit, daging dan tulang dari bagian-bagian karkas tersebut di atas, maka diperoleh komponen edible dan komponen non edible dari karkas. Komponen karkas edible ini merupakan bagian karkas yang dapat dimakan (daging dan kulit), sedangkan komponen karkas non edible merupakan bagian karkas yang tidak dapat dimakan (tulang). Hasil rataan bobot dan persentase karkas edible dan non edible disajikan pada

Tabel 1. Rataan bobot potong, bobot dan persentase karkas serta non karkas ayam broiler umur 30 hari

\begin{tabular}{lcc}
\hline Peubah & Jantan & Betina \\
\hline Bobot potong $\left(\right.$ g ekor $\left.^{-1}\right)$ & $1834,10 \pm 64,24 \mathrm{a}$ & $1659,40 \pm 72,02 \mathrm{~b}$ \\
Bobot karkas & & \\
$\quad\left(\right.$ g ekor $\left.^{-1}\right)$ & $1272,38 \pm 57,44$ & $1174,44 \pm 50,58$ \\
$(\%)$ & $69,38 \pm 2,13 \mathrm{~b}$ & $70,78 \pm 1,55 \mathrm{a}$ \\
Bobot non karkas & & \\
$\quad\left(\right.$ g ekor $\left.^{-1}\right)$ & $561,72 \pm 44,82$ & $484,96 \pm 35,58$ \\
$(\%)$ & $30,62 \pm 2,13 \mathrm{a}$ & $29,21 \pm 1,55 \mathrm{~b}$ \\
\hline
\end{tabular}

Angka disertai huruf kecil yang berbeda pada baris yang sama menunjukkan berbeda nyata $(\mathrm{P}<0,05)$ 
Tabel 3.

Hasil analisis menunjukkan bahwa jenis kelamin tidak berpengaruh terhadap bagian persentase karkas edible seperti daging dan kulit. Menurut Murawska et al. (2011) pada masa pertumbuhan, ayam broiler diawali dengan pertumbuhan tulang dengan cepat. Pada saat laju pertumbuhan tulang mulai menurun, maka laju pertumbuhan otot dan deposisi lemak meningkat. Hal tersebut menyebabkan bagian daging dan kulit belum terlihat perbedaan persentase yang signifikan pada ayam broiler yang dipotong saat umur 30 hari. Persentase daging pada penelitian ini, baik pada ayam broiler jantan maupun betina lebih tinggi daripada hasil penelitian Shahin dan Elazeem (2005) yaitu sebesar 60,45\% untuk ayam jantan dan 59,63\% untuk ayam broiler betina, tetapi persentase bagian kulit jauh lebih rendah (22,29-23,75\%). Perbedaan tersebut terjadi karena umur pemotongan ayam broiler pada penelitian tersebut jauh lebih tua (56 hari).

Hasil analisis menunjukkan bahwa ayam broiler yang dipotong pada umur 30 hari menghasilkan rataan persentase tulang yang nyata lebih besar pada ayam jantan daripada ayam betina. Hasil pengujian kualitas fisik daging ayam broiler jantan dan betina dalam penelitian ini disajikan pada Tabel 4.

Nilai $\mathrm{pH}$ merupakan indikator yang dapat mempengaruhi sifat sensori suatu daging ayam. Hasil uji-t menunjukan bahwa nilai $\mathrm{pH}$ daging ayam broiler tidak dipengaruhi oleh jenis kelamin, dan masih berada pada kisaran $\mathrm{pH}$ daging ultimate. Menurut Glamocija et al. (2015), nilai $\mathrm{pH}$ ultimate ayam broiler berkisar antara 5,7-6,0. Van Laack et al. (2000) menambahkan pH normal daging ayam broiler berkisar antara 5,96-6,07. Faktor yang mempengaruhi nilai $\mathrm{pH}$ meliputi genetika, proses handling, pemotongan, proses postmortem hingga waktu penyimpanan (Glamoclija et al. 2015).

Nilai keempukan daging pada penelitian ini juga tidak berbeda antara ayam broiler jantan dan betina. Nilai keempukan daging pada penelitian ini adalah 2,16-2,26 kg $\mathrm{cm}-2$. Hasil tersebut lebih tinggi dibandingkan penelitian Wahyuni (2017) sebesar 1,29-1,41 kg cm $\mathrm{cm}^{-2}$, walaupun demikian daging pada penelitian ini masih pada kisaran nilai keempukan untuk daging empuk. Pearson dan Young (1971), menyatakan kisaran keempukan daging terbagi atas

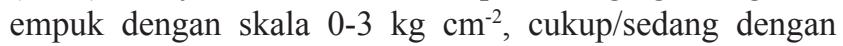
skala 3-6 kg cm-2 dan alot dengan skala $>6-11 \mathrm{~kg} \mathrm{~cm}^{-2}$.

Persentase susut masak sangat dipengaruhi oleh nilai $\mathrm{pH}$ dan komposisi lemak daging (Souza et al. 2011).

Tabel 4. Hasil pengujian kualitas fisik daging ayam broiler jantan dan betina

\begin{tabular}{lcc}
\hline Peubah & Jantan & Betina \\
\hline $\mathrm{pH}$ & $5,98 \pm 0,15$ & $6,07 \pm 0,04$ \\
Keempukan (kg cm-2) & $2,26 \pm 0,11$ & $2,16 \pm 0,15$ \\
Susut Masak (\%) & $36,32 \pm 2,38 \mathrm{a}$ & $42,50 \pm 1,90 \mathrm{~b}$ \\
Persentase air bebas (\%) & $29,45 \pm 1,44$ & $29,54 \pm 2,50$ \\
\hline
\end{tabular}

Angka disertai huruf kecil yang berbeda pada baris yang sama menunjukkan berbeda nyata $(\mathrm{P}<0,05)$
Persentase susut masak daging ayam broiler jantan secara statistik nyata lebih rendah dibandingkan daging ayam betina. Hasil ini diduga karena kandungan lemak pada daging ayam betina yang lebih banyak dibandingkan ayam jantan. Menurut Novele et al. (2008), ayam betina lebih mudah mendeposisi lemak tubuh dibandingkan ayam jantan. Menurut Souza et al. (2011), nilai pH dan deposisi lemak pada daging dapat mempengaruhi nilai susut masak daging setelah pemrosesan. Persentase lemak yang lebih tinggi akan membuat nilai susut masak yang lebih tinggi pula. Hasil susut masak pada penelitian ini sebesar $36,32 \%$ 42,5\%. Menurut Soeparno 2005, persentase susut masak daging berkisar antara 1,5\%-54,5\%. Daging dengan susut masak yang rendah mempunyai kualitas yang relatif lebih baik daripada daging dengan susut masak yang lebih besar, karena kehilangan nutrisi selama pemasakan akan lebih sedikit.

Daya mengikat air (DMA) adalah kemampuan protein daging mengikat atau menahan kandungan air (mengabsorbsi air) sebagai respon dari aplikasi kekuatan eksternal seperti pemotongan, pemasakan, dan penggilingan daging. DMA dapat diketahui melalui perhitungan kandungan air bebas dalam daging. Persentase kandungan air bebas pada penelitian ini secara statistik tidak dipengaruhi oleh jenis kelamin. Hasil persentase pada penelitian ini sebesar 29,45\%-29,54\%.

\section{Karakteristik Non Karkas Ayam Broiler}

Bagian tubuh ayam yang termasuk dalam komponen non karkas dalam penelitian ini adalah darah yang keluar, bulu, jerohan, lemak abdominal, kepala, leher dan kaki. Hasil pengamatan persentase dari komponen non karkas disajikan dalam Tabel 5.

Tabel 5. Rataan dan proporsi komponen non karkas ayam broiler jantan dan betina

\begin{tabular}{|c|c|c|}
\hline Peubah & Jantan & Betina \\
\hline Darah $(g)$ & $81,80 \pm 19,40$ & $61,20 \pm 17,96$ \\
\hline$(\%)$ & $4,44 \pm 0,98$ & $3,68 \pm 0,99$ \\
\hline Bulu (g) & $47,80 \pm 18,86$ & $43,80 \pm 16,44$ \\
\hline$(\%)$ & $2,62 \pm 1,08$ & $2,64 \pm 1,00$ \\
\hline Kepala (g) & $42,56 \pm 2,64$ & $37,16 \pm 3,02$ \\
\hline$(\%)$ & $2,32 \pm 0,18$ & $2,24 \pm 0,20$ \\
\hline Leher $(\mathrm{g})$ & $60,01 \pm 6,98$ & $51,42 \pm 17,07$ \\
\hline$(\%)$ & $3,27 \pm 0,33$ & $3,08 \pm 1,03$ \\
\hline Kaki (g) & $71,00 \pm 6,81$ & $58,84 \pm 7,71$ \\
\hline$(\%)$ & $3,88 \pm 0,40$ & $3,55 \pm 0,47$ \\
\hline Jerohan $(\mathrm{g})$ & $155,39 \pm 3,36$ & $147,70 \pm 3,17$ \\
\hline$(\%)$ & $8,47 \pm 2,33$ & $8,90 \pm 2,45$ \\
\hline Lemak abdominal (g) & $12,41 \pm 4,66$ & $13,02 \pm 4,89$ \\
\hline$(\%)$ & $0,67 \pm 0,23$ & $0,78 \pm 0,29$ \\
\hline Bobot yang hilang (g) & $90,75 \pm 16,27$ & $71,28 \pm 13,28$ \\
\hline$(\%)$ & $4,93 \pm 1,36$ & $4,36 \pm 1,96$ \\
\hline
\end{tabular}

Angka disertai huruf kecil yang berbeda pada baris yang sama menunjukkan berbeda nyata $(\mathrm{P}<0,05)$ 
Hasil pengujian menunjukkan bahwa persentase komponen non karkas antara ayam broiler jantan dan betina tidak berbeda. Peubah bobot yang hilang adalah besarnya kotoran yang terdapat dalam rempela dan usus ayam broiler, karena dalam penimbangan jerohan pada penelitian ini dilakukan setelah pencucian. Meskipun sudah dipuasakan sekitar 12 jam sebelum dilakukan pemotongan, tetapi sisa hasil pencernaan pakan yang dikonsumsi ayam broiler masih terdapat di dalam usus dan rempela.

Jerohan yang disampaikan dalam Tabel 5 diatas adalah kumpulan dari organ-organ jantung, hati, rempela, limpa, paru-paru, dan usus ayam. Rataan dari persentase bobot masing-masing komponen jerohan tersebut dalam penelitian ini adalah 0,49-0,50\%, 2,26-2,47\%, 1,53-1,68 $\%, 0,12-0,15 \%, 0,60-0,67 \%$ dan 3,37-3,51\% dari bobot potong atau bobot hidup ayam broiler. Menurut Murawska et al. (2011) dan Scanes et al. (2004), persentase komponen jerohan dalam penelitian ini berada dalam kisaran normal. Hal ini berarti bahwa organ-organ ayam broiler tersebut saat dilakukan penelitian berfungsi dengan baik. Dari komponen non karkas yang disajikan dalam tabel diatas, komponen kaki (ceker ayam) dan hati, rempela serta usus (bagian dari jerohan) mempunyai nilai ekonomis yang tinggi dan sangat diminati oleh masyarakat.

\section{KESIMPULAN}

Ayam broiler jantan yang dipotong pada umur 30 hari mempunyai bobot badan lebih besar, menghasilkan persentase karkas yang lebih kecil dengan persentase tulang karkas yang lebih besar serta memiliki kualitas fisik daging yang lebih baik daripada ayam broiler betina.

\section{DAFTAR PUSTAKA}

Aberle ED, Forrest JC, Gerrard DE, Mills EW, Hendrick HB, Judge MD, Merkel RA. 2001. Principles of Meat Scince. Ed ke-4. San Fransisco (USA); Kendall Hunt Publishing Company Iowa.

[BPS] Badan Pusat Statistik. 2016. Populasi Ayam Ras Pedaging Menurut Provinsi (Ekor). Jakarta (ID): BPS RI.

Badan Standardisasi Nasional. 2009. SNI 3924-2009. Mutu Karkas dan Daging Ayam. Jakarta (ID): BSN.

Bell, D.D., W.D. Weaver. 2002. Commercial Chicken Meat and Egg Production. 5th Edition. Springer Science and Business Media, Inc., New York, USA.

Direktorat Jendral Peternakan dan Kesejahteraan Hewan. 2010. Pedoman Produksi dan Penangan Daging Ayam yang Higienis. Jakarta (ID). DPKH

Glamoclija N, Starcevic M, Janjic J, Ivanovic J, Boskovic M, Djordjevic J, Markovic R, Baltic MZ. 2015. The effect of breed line and age on measurements of $\mathrm{pH}$ value as meat quality parameter in breast muscles (M. pectoralis major) of broiler chicken. Science Direct. 5:89-92

Hamm R. 1972. The Water Holding Capacity of Meat. Di dalam: Soeparno 2005. Ilmu dan Teknologi Daging. Yogyakarta (ID): UGM Pr.
Kartasudjana R, Edjeng S. 2006. Manajemen Ternak Unggas. Jakarta (ID); Penebar Swadaya.

Muiz A. 2016. Pengaruh penggunaan tepung daun binahong (andredera cordifolia) (ten) (stennis) sebagai feed additive terhadap kualitas karkas ayam pedaging. Jurnal Agrisains 17(1):54-61

Murawska D, Kleczek K, Wawro K, Michalik D. 2011. Age-related changes in the percentage content of edible and non edible component in broiler chickens. Animal Science 24(4): 532-539.

[NRC] National Research Council. 1994. Nutrient Requirements of Poultry. Ed ke-9. Washington DC (US). National Academy Press

Nittha P, Yaman MA, Rastina. 2017. Pengaruh pemberian pakan fermentasi limbah nanas (ananas comosus $l$. Merr) terhadap bobot badan dan persentase potongan karkas broiler. Jurnal Ilmiah Mahasiswa Veteriner 01(3):521-532

Novele DJ, Ng'ambi JW, Norris D, Mbajiorgu CA. 2008. Effect of sex, level and period of feed restriction during the starter stage on productivity and carcass characteristics of ross 308 broiler chickens in south africa. Int J Poult Sci. 6:530-537

Pearson AM, Young RB. 1971. Muscle and Meat Biochemistry. New York (US): Academic Pr.

Quniawan A, Arief II, Afnan R 2016. Performans produksi ayam pedaging pada lingkungan pemeliharaan dengan ketinggian yang berbeda di Sulawesi Selatan. Jurnal Veteriner 17(4): 622-633

Scanes CG, G Brant, ME Ensminger. 2004. Poultry Science. 4th Ed. Pearson. Prentice Hall, New Jersey.

Setiawan I, Sujana E. 2015. Bobot akhir, persentase karkas dan lemak abdominal ayam broiler yang dipanen pada umur yang berbeda. Seminar Nasional Fakultas Peternakan Unpad "Pengembangan Sistem Produksi dan Pemanfaatan Sumberdaya Lokal untuk Kemandirian Pangan Asal Ternak" hlm 563-567. Bandung (ID): Universitas Padjajaran

Shahin KA, Elazeem FA. 2005. Effects of breed, sex and diet and their interactions on carcass composition and tissue weight distribution of broiler chickens. Arch. Tierz., Dummerstorf .48 (6): 612-626

Soeparno. 2005. Ilmu dan Teknologi Daging. Yogyakarta (ID): UGM Pr

Souza XR, Faria PB, Bressan MC. 2011. Proximate composition and meat quality of broiler reared under different production systems. Brazilian Journal of Poultry Science 13(1): 15-20

Steel RGH, Torrie JH. 1993. Prinsip dan Prosedur Statistika Suatu Pendekatan Biometrik. Jakarta (ID). Gramedia Pustaka Utama

Van Laack R, Liu CH, Smith M, Loveday H. 2000. Characteristics of pale, soft, exudative broiler breast meat. Poult Sci. 79(7):1057-1061.

Wahyuni. 2017. Kualitas daging ayam broiler yang diberi pakan mengandung tepung konsentrat protein ulat hongkong [tesis]. Bogor (ID). Institut Pertanian Bogor. 